\title{
THE EFFECT OF ETHYLENE VINYL ACETATE METATARSAL PAD UPTAKE IN REDUCING METATARSAL PAIN IN FEMALE POLICE
}

\author{
Herawati Prianggi'), Sri Surini Pujiastuti²), Nur Rachmat ${ }^{2)}$ \\ 1)Masters Program in Public Health, Universitas Sebelas Maret \\ ${ }^{2)}$ Health Polytechnics Ministry of Health Surakarta
}

\begin{abstract}
Background: Plantar pressure reduction with the use of an insole has been demonstrated to effectively diminish the subjective rating of metatarsalgia. Metatarsal padding is currently the main strategy for reducing the excessive pressure and thus relieving the pain under the metatarsal heads. However, pressure reductions are usually diverse and limited. The multi-step accommodative insole is fabricated by sequential foam padding on Plastazote using Ethylene Vinyl Acetate under dynamic accommodation in daily walking. This study aimed to examine the effect of ethylene vinyl acetate metatarsal pad uptake in reducing metatarsal pain in female police.

Subjects and Method: A quasy experiment with no control group was conducted from February to March 2019 in di police office, Central Java. A sample of 22 female police was selected by total sampling. The dependent variable was metatarsal pain. The independent variable was ethylene vinyl acetate metatarsal pad uptake.

Results: Mean of metatarsal pain after ethylene vinyl acetate metatarsal pad uptake (Mean= 3.86; $\mathrm{SD}=0.30$ ) was lower than before $(\mathrm{Mean}=5.95 ; \mathrm{SD}=0.30)$ and it was statistically significant $(\mathrm{p}<0.001)$.

Conclusion: Metatarsal pain is lower after ethylene vinyl acetate metatarsal pad uptake.
\end{abstract}

Keywords: ethylene vinyl acetate metatarsal pain, metatarsal pad

\section{Correspondence:}

Herawati Prianggi. Masters Program in Public Health, Universitas Sebelas Maret. Jl. Ir. Sutami 36A, Surakarta 57126, Central Java. Email: herawatiprianggii@gmail.com. Mobile: 089670447344. 